\title{
Millest räägivad eesti õppijakeele käändeasendused?
}

\author{
PILLE ESLON \\ Tallinna Ülikool
}

Ülevaade. Artiklis kirjeldan mõningaid tendentse, mis on jälgitavad eesti keele objektikäänete kasutamisel. Tegu on sünkroonse uurimusega, mille aluseks eesti õppijakeele ja kirjakeele võrdlev korpusest tulenev ning korpuspõhine analüüs. Korpusest tuleneva analüüsiga leitakse ühele või teisele keelekasutusvariandile iseloomulikud nähtused, mille uurimist jätkatakse korpuspõhise analüüsiga. Lähtepunktiks on arusaam, et õppija keelekasutus peegeldab keelele omaseid arenguid, mille väljenduseks on muuhulgas ka objektikäänete asendused ja varieerumine. Need protsessid ei tuleks esile, kui keelesüsteemis puuduks vajalik valmidus. Korpusanalüüsi tulemusel ilmnevad ühelt poolt keeleülekandest tingitud ja teisalt eesti keele soomeugrilisest olemusest johtuvad nähtused, mida keelendi või kategooria tasandilt lähtuv kontrastiiv- ja veaanalüüs esile ei too. Seetõttu on artiklis tähelepanu pööratud ka üldistele põhimõtetele, millele objektikäänete kasutuse korpusanalüüs tugineb.

Võtmesõnad: objektikäänded; vormivariatiivsus; korpusest tulenev ja korpuspõhine võrdlev analüüs; eesti kirjakeel; eesti õppijakeel 


\section{Korpusaines ja uurimisobjekt}

Artiklis käsitlen eesti õppijakeelele omaseid tendentse objektikäänete kasutamisel Tallinna Ülikooli eesti vahekeele korpuse tekstide põhjal. Valim koosneb üle 500000 sõne sisaldava morfoloogiliselt analüüsitud tekstikorpuse verbifraasidest, mis on leitud sõnaliigimärgendi järgi. Nende hulgast on välja filtreeritud kõik verbivormid 2-3-sõnalise kontekstiga verbist paremale ja vasakule ${ }^{1}$. Käesoleva uurimuse tarbeks olen kasutanud verbist paremale jääva kontekstiga fraase - kokku 38251 verbifraasi, neist viiendik ehk 7939 olid objektifraasid. Kuna eesti keeles on grammatiliste käänete vormihomonüümia sage nähtus ning valimis leidub kontekste, mille põhjal käändevormi valiku üle on raske otsustada (nt võtta eriala, viskaks prügi, viima klaastaara), siis suurendas see analüüsitavate objektifraaside hulka.

Käesoleva artikli tarvis olen vaadelnud eraldi objektifraaside alarühma, milles õppijad on üht grammatilise käände vormi kasutanud teise asemel. Üldse on nominatiiviga tehtud 696 asendust, sellest 506 on juhtumid, kui nominatiiviga on asendatud partitiivi ja 190 on juhtumid, kui nominatiiviga on asendatud genitiivi. Partitiiviga on tehtud kokku 170 asendust: 120 juhtumit, kus partitiiv asendab genitiivi ja 50 juhtumit, kus partitiiv asendab nominatiivi. Genitiiviga on kokku 81 asendust: 62 juhtumit, kus genitiiv asendab partitiivi ja 19 juhtumit, kus genitiiv asendab nominatiivi (vt tabel 1 ).

Kõige regulaarsem on partitiivi asendamine nominatiiviga (506 kasutusnäidet): ${ }^{\star}$ armastab jook, ${ }^{*}$ óppisite seal arvutiópetus, ${ }^{\star} v a ̈ l j e n d a d a$ emotsioonid, ${ }^{*}$ vótan natukene lilled, ${ }^{\star}$ võrreldes teadmised jne. Vastupidine protsess ehk nominatiivi asendamine partitiiviga on tunduvalt harvem nähtus - vaid 50 korda: ${ }^{*}$ oppis pähi programmerimise keeleid, *vaikiti maha kogu pagulaskirjandust, ${ }^{*}$ vahetada oma keemiatoodet, ${ }^{*}$ teha hea jõulukingitust, ${ }^{*}$ söö ära kõike marju, ${ }^{*}$ saada hea kõrgharidusi jne.

Verbifraaside formaalse eraldamise Tallinna Ülikooli eesti vahekeele korpuse tekstidest teostas Kairit Sirts. 
TABEL 1. Grammatiliste käänete asendused eesti õppijakeele objektifraasis

\begin{tabular}{|l|c|}
\hline Asenduse suund & Sagedus \\
\hline Nominatiiv asendab partitiivi & 506 \\
\hline Nominatiiv asendab genitiivi & 190 \\
\hline Partitiiv asendab nominatiivi & 50 \\
\hline Partitiiv asendab genitiivi & 120 \\
\hline Genitiiv asendab nominatiivi & 19 \\
\hline Genitiiv asendab partitiivi & 62 \\
\hline
\end{tabular}

Partitiivi ja nominatiivi on genitiivi asemel kasutatud ühtlasemalt: nominatiivi 190 korral ( ${ }^{*}$ oppis selgeks üks vana laul, ${ }^{*}$ võttis korv, ${ }^{*}$ valisin saksofon, ${ }^{*}$ unustasime meie rahvuskultuur, ${ }^{*}$ tegin pealkiri, ${ }^{*}$ sünnitama üks poiss jne) ja partitiivi 120 korral (võttis suunda, võttis mind tööle, veetsime oma vaheaega, ${ }^{*}$ varastas kotti noormees, valisin teist eriala jne). Vastupidine protsess ehk nominatiivi asendamine genitiiviga pole olnud märkimisväärne - 19 korda: ${ }^{*}$ viidi läbi ürituse, ${ }^{*}$ taastati iseseisvuse, ${ }^{*}$ säilitada oma keele, ${ }^{*}$ sooritan kõike eksami jne; veidi enam on genitiiviga asendatud partitiivi - 62 korral: ${ }^{\star}$ armastab selle töö, ${ }^{\star}$ tänasid puuraiujate ja kutsusid, ${ }^{\star}$ tunnevad selle traditsiooni, ${ }^{\star}$ tahaks ópida eesti keele jne.

\section{Lähtepunkt ja eesmärgid}

Objektikäänete korpusanalüüsis lähtun vormide ja samalaadsete konstruktsioonide tekstisagedusest - seega keelekasutaja eelistustest. Konstruktivistid on seisukohal, et samalaadselt vormistatud ja sageli kasutatavad konstruktsioonid kinnistuvad teatud konventsionaalse tähenduse või semantilise kontseptiga (vt Croft 2001; Chang jt 2002; Boas 2002; Östman \& Fried 2005 jt), millele tuginedes keeleõppija aktiveerib sõnavara, valib vastava morfosüntaktilise vormistuse, kavandab intonatsioonistruktuuri ja häälduse. 
Tekstisageduse alusel esile toodud konstruktsioonide lingvistiline kirjeldus sisaldab valikulist ja piiratud semantilist ning morfosüntaktilist informatsiooni (vt nt Sahkai 2006; Sepper 2006; Kostenko 2009), milles peegeldub keelekasutuseelistuste põhjal ilmnenud leksikaalsete üksuste, konstruktsioonide, vormide, kategooriate jm süsteemne staatus. Nii vormide üldises tekstisageduses (paradigmaatiline aspekt) kui ka keelekasutuses eelistatud konstruktsioonides sisalduvate vormide statistikas (süntagmaatiline aspekt) kehtivad teatud seaduspärad, mis iseloomustavad keelt ja selle arengut. ${ }^{2}$

Eelnevalt olen võrrelnud eesti õppijakeele ja kirjakeele valimite alusel kõikide käändevormide (sh objektikäänete) tekstisagedust ja käänete valikulist kasutamist tekstiloomes eelistatud konstruktsioonides (vt Eslon \& Matsak 2009; Eslon 2009). Objektnoomeni käändekasutuse võrdleva uurimuse põhjal eesti õppijakeeles ja kirjakeeles (vt Eslon 2010b), õppijakeele objektifraasi käändeasendustes (vt Eslon 2010a) ning võrreldes objektikäänete kasutust ajakirjandustekstides (tekstisagedus) ja fraseologismides (sõnastikusagedus) (vt Eslon \& Õim 2010a) olen jõudnud arusaamani, et grammatiliste käänete kasutuses ilmneb rida eesti keelesüsteemile omaseid jooni, mis kõnelevad ennekõike eesti keele soomeugrilisest olemusest:

- õppijakeeles ja kirjakeeles asendatakse partitiivi ja genitiivi peamiselt nominatiiviga;

- nominatiiv ja partitiiv moodustavad vastanduse, mille markeerimata liige on nominatiiv ning markeeritud liige partitiiv;

\footnotetext{
2 Näiteks Joseph Greenberg on Evi Šteinfeldti koostatud "Vene keele sagedussõnastiku” (1963) alusel näidanud, et erinevatesse semantilistesse gruppidesse kuuluvate nimisõnade käändevormid esilduvad tekstides erineva tõenäosusega (Greenberg 1990: 208). Sama tulemuseni on tunduvalt hiljem jõutud ka kahe korpusainese võrdlemisel (vt Kopotev 2008: 137 jj), mille maht pole kaugeltki lähedane, ent saadud analüüsitulemused lahknevad kuni $4 \%$, mis jääb piirväärtusest (5\%) alla. Seega on keelendite sagedusgrammatika seisukohast saadud tulemused adekvaatsed. Samalaadselt on ka eesti kirjakeele ja õppijakeele käändekasutuse võrdlevas uurimuses (vt Eslon \& Matsak 2009) välja toodud seosed sõna semantika ja käändevormide valikulisuse vahel sageli esinevates konstruktsioonides.
} 
- genitiivi kasutusala kitseneb, genitiiv marginaliseerub (genitiivi põhifunktsioon taandub possessiivsuse väljendamisele);

- grammatiliste käänete varieerumist ja käändeeristuse neutraliseerumist võib pidada paradigma lihtsustumisega seotud morfofonoloogiliste protsesside tulemuseks, mis on keelesüsteemile omane nähtus, ei tulene keeltevahelisest mõjust, ei ole hinnatav mitteaktsepteeritava keelekasutusena ega seostu vaid grammatiliste käänete vormihomonüümiaga - oluline roll on transitiivverbi definiitsuse tuhmumisel, tähendus- ja rektsioonimuutustel, sõnajärjel, lause infostruktuuril;

- grammatiliste käänete asendused eesti õppijakeeles on seotud ühelt poolt eesti keelele omase käändevariatiivsusega ning teisalt keeltevahelisest mõjust tingitud negatiivse keeleülekandega.

Oma töös olen arvesse võtnud nende lingvistide seisukohti, kes püüavad keeles toimuvaid muutusi määratleda kas keeleomase variatiivsusena või keeltevahelisest mõjust tingitud nähtusena (vt nt Aikhenvald 2007; Heine \& Kuteva 2008; Ehala 2009b). Sünkroonne varieerumine on keelekasutusele omane tunnusjoon, mis kõneleb keele arengupotentsiaalist, sageduse ja produktiivsuse dialektikale tuginevatest tendentsidest ning võimalikest muutustest (vt nt Nikolaev \& Niemi 2006; Lüdeling \& Evert 2003; Lüdeling jt 2000; Kaalep 2010; 2009). Keeltevaheline mõju tugineb keelte objektiivsele, tunnetatud ja oletatavale sarnasusele (vt Ringbom 2007: 7-9) ning väljendub positiivse või negatiivse keeleülekandena (vt Kaivapalu, Martin 2007: 132-133; Kaivapalu 2008: 93-119).

Käesoleva uurimuse eesmärk on vastata järgmistele küsimustele: 1) mis eesti keele objektikäänete kasutamisel tuleneb keelesüsteemi arengust ega sõltu keeltevahelisest mõjust; 2) missugused õppijakeelele omased protsessid objektikäänete asendamisel johtuvad keeleülekandest.

Nendele küsimustele vastates lähtun järgmisest: 1) õppija keelekasutuses peegelduvad kirjakeele arengule omased protsessid, millele viitavad ka objekti käändeasendused; seetõttu ongi õppijakeele uurimine mõttekas tegevus; 2) õppijakeeles ilmnevad protsessid poleks edukad, kui eesti keele süsteemis puuduks vajalik valmidus. 


\section{Tähelepanekuid objektikäänete kasutamisest}

\subsection{Mis objektikäänete kasutamisel võib tuleneda keelesüsteemi arengust?}

Eesti keelele omaste tendentside kohta objektikäänete kasutamisel saab järeldusi teha käändevariatiivsuse alusel. Õppijakeele käändeasendused viitavad kahele tendentsile: ühelt poolt nominatiivi kasutusala laienemisele valdavalt partitiivi ja vähemal määral genitiivi arvelt ning teisalt partitiivse objekti kasutusala laienemisele genitiivi arvelt (vt tabel 1).

Nominatiivse objekti kasutusala laienemine partitiivi ja genitiivi arvelt (korrektseid juhtumeid vastavalt 100 näidet 506-st partitiivi asendusest ja 21 näidet 190-st genitiivi asendusest) tugineb verbi definiitsuse tuhmumisele, mille tulemusel avardub aspektverbide klass ning kasvab objektnoomeni käändevariatiivsus, vrd leian uued sõbrad uusi sõpru, teed vastavad järeldused $\sim$ vastava järelduse $\sim$ vastavaid järeldusi, anna vastus $\sim$ vastust, lõpetati töö $\sim$ tööd, andis välja kalendri $\sim$ kalendrit, tuleb leida vastus, leiab vastuse vastust. Samas väärib tähelepanu, et õppijakeeles on objekti käändevariatiivsuse korral eelistatud kasutada enamasti nominatiivi. Kas tegu võiks olla õppijale omase lihtsustamise või eesti keele grammatiliste käänete kasutamisele iseloomuliku nähtusega? Valter Tauli on pidanud nominatiivi eelistamist objektikäändena keeleomaseks loomulikuks lihtsustumiseks (Tauli 1968: 62-63), mida on näidanud ka hilisemad, sh õppijakeele ja kirjakeele võrdlevad uurimused (ülevaatlikult Eslon \& Õim 2010a: 70, 82-84; Eslon 2010a: 19-28; Eslon 2010b: 45-53). Diakroonilistele andmetele tuginedes (vt Lees 2004) ning võrdluses teiste soomeugri keeltega (vt Larjavaara 1991; Grünthal 2003; Huumo 2006 jt) saab järeldada, et eesti keele objektikäänete varieerumine on olnud laineline, kuid mitte ühesuunaline protsess, minetamata samas oma soomeugrilist olemust (vt ka Eslon \& Õim 2010a: 69-71, 82-83).

Partitiivse objekti kasutamine genitiivi asemel (120 näidet) ei ole seotud referendi elusa / elutu tunnusega; genitiivi asendamisel partitiiviga on elusat objekti tähistatud personaalpronoomeniga, mille parti- 
tiivset kasutust ei saa käsitleda käändeasendusena, nt võtsite mind/mu tööle. Seega pole tegu akusatiivistumisega ehk võõrmõjudel tekkinud keeletunde nürinemise tagajärjega ega süstemaatilise kõrvalekaldega, vaid eesti keelele iseloomuliku soomeugrilise tendentsiga, millest on põhjalikult kirjutanud juba Karl Kont, taunides partsiaalobjekti ületaotluse vastu alustatud võitlust:

Partitiiv viitab siin peamiselt põhisõna tegevuse määramatusele, mittekonkreetsusele --- Hoopis vähem oluline on asjaolu, kas kõnesolev tegevus on tulemuslik ja ajaliselt lõpetatud või mitte. --- Eesti keeles on paljudel juhtudel seda laadi indefiniitsust väljendavat partsiaalobjekti peetud keeleveaks või taunitavaks võõrapärasuseks. Eesti vanemas kirjakeeles --- esineb partsiaalobjekti massiliselt seal, kus see pole millegagi õigustatud. Võitlust partsiaalobjekti ületaotluse vastu alustati soome grammatika positsioonidelt. (Kont 1963: 98-99.)

Kont jätkab Johannes Aavikuga diskuteerides, et nii kuulutati vigasteks ka rahvapärased ja õiged partsiaalobjekti kasutused, mis kuuluvad enamasti fraseoloogilise objekti alla.

Eesti õppijakeele 120-st genitiivi asendusest partitiiviga on üle poole juhtumitest sellised, kus tegu keeleomase käändevariatiivsusega: andis võimaluse $\sim$ võimalust, põhjuse $\sim$ põhjust, vastuse $\sim$ vastust, annab tulemuse $\sim$ tulemust, õiguse $\sim$ õigust; valib elukutse $\sim$ elukutset, teise eriala $\sim$ teist eriala; võtavad suure koormuse $\sim$ suurt koormust, võttis suuna suunda, suure hoo suurt hoogu; leidsin ühise keele $\sim$ ühist keelt; said agressiivse vormi $\sim$ agressiivset vormi; kaotas oma armastuse $\sim$ armastust; kirjutas oma arvamuse $\sim$ arvamust, kirjutas alla lepingu lepingut; lõpetab õppimise óppimist, lõpetan selle ülikooli seda ülikooli jne.

Analoogselt nominatiivi kasutusala laienemisega on ka partitiivi eelistamine genitiivi asemel seotud verbi definiitsuse tuhmumise ja aspektverbide klassi avardumisega (nt andma, võtma, tegema, saama, panema, pidama, leidma, kaotama, kirjutama, lópetama, saavutama, valima jt). See verbi leksikaalgrammatilises perifeerias toimuv areng 
loob soodsa pinnase objekti käändevariatiivsusele, kuna tegevuse kulgemist või selle iseloomu pole konkretiseeritud ei morfoloogiliselt ega diskursiivselt. Näiteks verbi tegema on objektifraasis da-infinitiivi vormis kasutatud 120 korda, neist diskursiivseid sõnu sisaldavaid fraase 64 ja mittesisaldavaid 56. Kui aga vaadata, mida 64-s objektifraasis diskursiivsete sõnadega on konkretiseeritud, siis selgub, et kõige sagedamini on konkretiseeritud objekti (42 fraasi), ligi kolm korda harvem tegevust (14 fraasi) ja viis korda vähem tegijat ( 8 fraasi). Näiteks: objekti kvalitatiivne ja kvantitatiivne täpsustamine (teha ilusad hambad, *teha igavat asju, teha mõned ained, teha igasuguseid asju), tegevuse kvantitatiivne, lokaalne, tegevuslaadiline täpsustamine ( ${ }^{\star}$ teha vähem vead, teha rohkem kahju, teha enam politseoperatsioneid, teha Kohtla-Järvel algtase, teha Tallinnasse sümbol, teha kiiret ülevaadet), tegija täpsustamine (teha midagi ise, teha seda inimestega) jne (näited pärinevad VI Muutuva keele päeval koos Katre Õimuga tehtud ettekandest, vt Eslon \& Õim 2010b). Tegemaverbi definiitsuse tuhmumine objektifraasis on suuresti seotud sellega, et objektifraasis pole fookuses mitte tegevus ja selle markeerimine, vaid objekt ja selle kvalitatiivne-kvantitatiivne identifitseerimine.

Kuna definiitsust/indefiniitsust peetakse muutustetundlikuks universaalseks kategooriaks, siis on seda kategooriat käsitletud keelesüsteemi sisemiste muutuste ühe võimaliku allikana. Erinevates keeltes võivad need muutused kulgeda kas samaaegselt või olla ajalises nihkes, kuid need protsessid kulgevad igas keeles iseseisvalt. (Aikhenvald 2007: $1-66$.

\subsection{Mis eesti keele objektikäänete kasutamisel võib tuleneda keeltevahelisest mõjust?}

Eespool nimetasin, et vene emakeelega õppija asendab nominatiiviga enamasti partitiivi (506 juhtumit, millest korrektse keelekasutuse näiteid oli 100), tunduvalt harvem genitiivi (190 juhtumit, millest korrektse keelekasutuse näiteid oli 21). Ülejäänud 320 partitiivi asendamist nominatiiviga on õppija emakeele mõjuline ebareeglipärasus, mis võib tule- 
neda väärast õpetamis- või õppimisstrateegiast. Tegu on partitiivverbide rektsioonivigadega: *armastab meie maa, oma abikaasa; *armastame kingitused, kokteilid; ${ }^{\star}$ armastan ilus muusika, kiirus; ${ }^{\star}$ jõime ainult mahl,

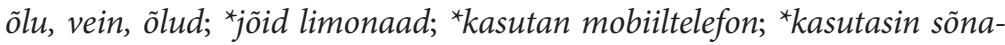
raamat; ${ }^{\star}$ kirjeldab oma emotsioonid; ${ }^{*}$ kirjutan kiri; ${ }^{\star}$ kuulame laulud, rokk;

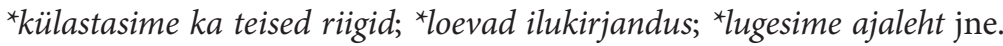
Ebareeglipärane partitiivi asendamine nominatiiviga on õppijakeeles seotud nende verbidega, mis õppija emakeeles (vene keel) nõuavad akusatiivi: óppima, armastama, vaatama, teadma, tegema, tahtma, lugema, nägema, kasutama, näitama, kuulama jne, vrd óppima mida? - yчumb, изучать что?; armastama keda-mida? - любить кого-что?; vaatama keda-mida? - смотреть на кого-что?, что?; teadma mida? - знать кого-что?; tegema mida? - делать что? jne. Kuna ebareeglipärased partitiivi asendused nominatiiviga on eranditult seotud elutu referendiga, siis annab see alust arvata, et emakeelset rektsioonimalli rakendades on järgitud käändeküsimust (elutu referendi korral langeb vene keele akusatiiv kokku nominatiiviga). Siit tuleneb ka oletus eksitavast õpetamisvõi õppimisstrateegiast, kui elutut referenti samastatakse automaatselt eesti keele nominatiivse totaalobjektiga. See on mugav ja samas kooskõlas emakeelse otsesihitise rektsioonimalliga. Tegu on õppija emakeele mõjuga ja sellest tingitud objektireeglite lihtsustamisega.

Analoogne seis on ka genitiivi asendamisel nominatiiviga: aspektverbe lópetama, valima, andma, saama, tegema, murdma, kirjutama, leidma, ostma, võtma, panema jt on ebareeglipäraselt kasutatud 165-1 korral 190-st. Asenduse tulemusena muutub subjekti-objekti vaheline piir ebakindlaks (vt ka Pool 2010), nt ${ }^{*}$ andis välja kalender, ${ }^{*}$ annab ülevaade, ${ }^{*}$ avab hing, ${ }^{*}$ kirjutas teos, ${ }^{*}$ loob maailm, ${ }^{*}$ tapsi mees, ${ }^{*}$ teeb esileht, ${ }^{*}$ tekitas hea ja sõbralik atmosfä̈r, ${ }^{*}$ tõmbaks kast, ${ }^{\star}$ vahetaks nimi, ${ }^{\star}$ võttis korv, ${ }^{*}$ ópivad muud erialad jne. Tegu on õppija emakeele mõjust tingitud ebareeglipärasustega nagu ka partitiivi asendamisel nominatiiviga, kuna sageli kasutatud aspektverbide venekeelseteks vasteteks on otsesihistist nõudvad verbid, nt lópetama - кончать что?, valima - выбирать когочто?, andma - давать что?, saата - получать что? jne. Toimib sama- 
laadne emakeelemõjuline lihtsustumine, millest oli eespool juttu. Väärib tähelepanu, et genitiivi asendamisel nominatiiviga see protsess avardub ja laieneb diferentseerimatult nii elusale kui ka elutule referendile. Seda toetab omakorda eesti õppijakeele sõnajärg: emakeele mõjul eksitakse põhiliselt V2-reegli vastu (vt Kaivapalu 2010; Metslang \& Matsak 2010) ning sellest tulenevalt on subjekti-objekti vahele raske piiri tõmmata. Johtuvalt lause infostruktuurist on subjekti-objekti piiri hajusust märgatud ka eesti kirjakeeles (vt Lindström 2006; Eslon \& Õim 2010a), samuti teistes tüpoloogiliselt erinevates keeltes nagu hispaania ja portugali keel, kus arengud verbimorfoloogias (nt ajavormide taandumine) põhjustavad seda, et subjekt nihkub fookusesse (vt Posio 2008). Järelikult viitavad õppijakeele ebareeglipärased genitiivse objekti asendused nominatiivsega tunduvalt avaramatele protsessidele keelesüsteemi arengus, aidates neid aduda.

\section{Miks objektikäänete asendused ja variatiivsus laienevad?}

Keeltevahelisest mõjust tingitud protsessid poleks nii edukad, kui eesti keeles puuduksid selleks vajalikud eeldused nagu tegevuse indefiniitsus ja aspektverbide klassi avardumine partitiiv- ja perfektiivverbide arvelt (vt Vaiss 2004), verbi aspektiliste tähenduste markeerimine objektikäänetega, objekti kvantifitseerimine (vt Larjavaara 1991; Rajandi, Metslang 1979; Sulkala 1996; Huumo 2006), käändeparadigma lühenemine ja muutkondade lihtsustumine ning seda põhjustavad muutemorfoloogilised protsessid ja laadivahelduse kadu (vt Lüdeling jt 2000; Lüdeling \& Evert 2003; Nikolaev \& Niemi 2006; Kaalep 2010), rööpvormide kuulutamine normipärasuseks, grammatiliste käänete neutraliseerumine põhjustatuna vormihomonüümiast või lause pragmaatikast ja infostruktuurist, tekstisageduse ja kasutuseelistuste seos vormi markeerituse/markeerimatusega (vt Eslon \& Õim 2010a) jm. Eespool tõin välja rea eesti keelesüsteemile omaseid jooni (vt lk 48-49), mis on õnnestunud esile tuua tänu varasemale eesti kirjakeele ja õppijakeele käände- 
kasutuse võrdlevale analüüsile. Siinkohal tahaksin veel kord rõhutada neid momente, mis seonduvad grammatiliste käänete markeerituse/ markeerimatuse ja kasutussagedusega.

Martin Ehala on kirjutanud (1997; vt ka 2009a), et eesti käändeparadigma algvormi tunnustele vastab kõige paremini mitmuse genitiivi vorm: võimalikult vähe markeeritud, määrab muuttüübi ja tüveteisendused ning on aluseks vormisünteesile. Genitiivi alusel "on võimalik tuvastada enamik tüve morfoloogiliselt olulisi tunnuseid, välja arvatud astme- ja kujuvahelduslikkus". Nimetava käändega seoses pole seda täheldatud: "selle vormi algvormiks valimise kasuks kõneleb vaid ta markeerimatus". Kõige markeeritum kääne on partitiiv, kuna on kõigi eespool nimetatud tunnuste suhtes negatiivne (vt Ehala 1997: 372-375). Niisiis võib eesti käändesüsteemi tuumelemendiks pidada genitiivi, mis on sellisena kõige enam muutustele avatud grammatiline kääne. Seda näitavad nii eesti õppijakeele kui ka kirjakeele käändeasendused (vt Eslon 2009; 2010b; Eslon \& Õim 2010a): nominatiiv ja partitiiv avardavad oma kasutusala genitiivi arvelt (vt tabel 1); nii paradigmaatilises kui ka süntagmaatilises aspektis jääb genitiiv kasutussageduselt alla partitiivile ja nominatiivile. On igati loogiline, et morfoloogiliselt markeerimata genitiiv on muutumas marginaalseks - ka see räägib genitiivi algvormiks sobimise poolt. Grammatiliste käänete kasutamisel objektikäänetena on eesti keeles genitiivile eelistatud enamasti partitiivi, kusjuures mõlemat käänet võib asendada nominatiiviga, "ilma et sellest tekiks mingit ohtu selgusele” (Tauli 1968: 62-63). Näiteks Vikerraadio intervjuust kuuldud fraasi Oleks tore neile pakkuda selline tore üritus saab transformeerida nii genitiivset kui ka partitiivset objekti kasutades (sellise toreda ürituse sellist toredat üritust), ilma et oleks ohtu mõtte selgusele. Samas tajub emakeelekõneleja, et kuigi partitiivi, vähemal määral ka genitiivi kasutus on võimalik, eelistab ta ikkagi nominatiivi. Lisaks ei ole genitiivi põhifunktsioon objektilisuse edastamine, vaid possessiivsuse väljendamine.

Kui eesti genitiiv objektikäänete seast taandub, siis hakkab seda kohta täitma nominatiiv, sest see kääne on võrreldes partitiiviga markeerimata, samas kui partitiiv on kõikide muutemorfoloogiliste tunnuste suhtes 
negatiivne ning seetõttu grammatilistest käänetest kõige markeeritum (vt eespool). Kujuneb välja nominatiivi ja partitiivi vastandus ning nominatiiv kinnistub vastanduse markeerimata liikmena. Seetõttu on nominatiivil avaram funktsionaalne potentsiaal kui partitiivil, mida näitab ka eesti õppijakeele, kirjakeele ja fraseoloogilise ainese käändekasutus (vt Eslon \& Matsak 2009; Eslon 2010a; 2010b; Eslon \& Õim 2010a). Järelikult on loomulik ja keeleomane, et objektikäänete kasutusreeglite lihtsustumine toimub nominatiivi kasuks. Seda tendentsi toetab ka partsiaal- ja totaalobjekti eristuse märkamatu tuhmumine ning objekti käändeerisuste neutraliseerumine (vrd Meie eesmärk on tõsta inimene inimest esile). Teisalt toetab seda protsessi käändeparadigma lühenemine ja lihtsustumine, enamasti ühe- ja kahesilbiliste avaratähenduslike substantiivide vormihomonüümia arvelt. Riho Grünthal on näidanud, et liivi keele genitiivi-nominatiivi eristamatuse ja käändeparadigma lühenemise tõttu võeti appi muud keelevahendid (ennekõike sõnajärg), mida nende käändetähendustega seoses kasutama hakati. Ta on pidanud seda keelesüsteemi säilitavaks nähtuseks, mis on universaalne arenguseadus (Grünthal 2003). Analoogseid tendentse võib märgata ka slaavi keeltes (vt Nuckols 2007).

Lõpetuseks tahaksin öelda, et eesti õppijakeeles nagu igas teiseski õppijakeeles (olgu aluseks aktsepteeritava või mitteaktsepteeritava keelekasutuse näited) kajastuvad õpitava kirjakeele süsteemile omased arengutendentsid. Vahe on vaid selles, et õppijakeeles tulevad need selgemalt esile, kuna keeleõppija teeb oma valikud ja loob assotsiatiivseid seoseid sisemisele loogikale tuginedes (emakeele ja õpitava keele objektiivne, tunnetatud või oletatav sarnasus), mille põhjal ta hakkab õpitava keele süsteemi enda jaoks uuesti üles ehitama. Selles tugineb ta keelekasutuses sageli esinevatele terviküksustele (samalaadselt vormistatud leksikaalsed üksused ja morfosüntaktilised konstruktsioonid), mille tähendust, struktuuri ja vormistikku ei saa vaadelda eraldi, vaid ühtse tervikuna. Niisugused terviküksused tulevad esile keele kasutusmustreid uurides. 


\section{5. Ääremärkusi keelekasutuse uurimise kohta}

Nii käesolevas uurimuses kui ka eelnevates eesti õppijakeele ja kirjakeele objektikäänete võrdlevas analüüsis olen arvestanud keelendite ilmnemise tõenäosusega meie keelekasutuses, rakendanud eesti keele tarkvara ja klasteranalüüsi, mis on võimaldanud leida keelekasutusele iseloomulikud ja sageli esinevad konstruktsioonitüübid koos neile omase, kuid piiratud sõnavara ja vormistikuga. See on lubanud keelekasutuse seisukohalt olulise keeleainese valikul vältida subjektiivseid individuaalseid eelistusi.

Loomulikult ei lahene siinkohal kõik uurimistööga seotud probleemid. On tähtis, mis saab edasi, kuidas ja millest lähtudes kvantitatiivse analüüsi tulemusi interpreteerida ning andmeid klassifitseerida (vt Smith jt 2011: 163-164). Korpuse põhjal esile toodud konstruktsioonitüübid, leksikaalsed üksused ja lemmad on algmaterjal, millest lingvist lähtub, kui esitab küsimuse, miks keelekasutuseelistused on just niisugused, nagu need on. Sellest võib omakorda tuleneda rida vastakaid lingvistilisi hüpoteese, mis vajavad edasist kontrollimist eksperimentide, küsitluste, tajutestide jm abil. Keelekasutusest tuleneva lähenemise eelis selles peitubki, et uurija ei otsi lingvistilisi tõestusi oma peas tekkinud hüpoteesi(de)le ega keskendu ühe või teise vealiigi ilmnemisele ja selle põhjuste otsimisele, vaid püüab interpreteerida seda, mis keelekasutusest ilmneb (vt Tognini Bonelli 2001; 2002; Hanston 2002; Granger 2004; Stubbs 1996; Hoey jt 2007).

Keelekasutuse uurimisel on kindel metodoloogiline roll ka keeltevaheliste seoste ja keelte vastastikuse mõju mõistmisel (Fernándéz 2007: 520,522 ). On selge, et keeletarkvara, statistiline analüüs jm (nt Scott 2008) võimaldavad kiiresti leida mitte ainult ühe keele erinevate kasutusvariantidele iseloomulikud, vaid ka erinevatele keeltele omased sageli esinevad leksikaalsed üksused ja morfosüntaktilised konstruktsioonid (nt Stubbs 1996: 126-154; Eslon 2010a). Leitud keelekasutusmustrite võrdlemine kas erinevate keelte (nt Kostenko 2010) või ühe keele erinevate kasutusvariantide vahel toob esile keelekasutusele omased tendent- 
sid, samalaadsed arengud ning erinevused. See on kahtlemata kiirem viis jõuda keelekasutust, erinevaid keeli ja nende omandamisprotsessi ühendavate seosteni.

Kõigel eespool kirjeldatul on õppijakeele ja kirjakeele võrdlevas uurimuses kindel metodoloogiline ja pedagoogiline väärtus, mida ei saa väita kontrastiiv- või veaanalüüsile tugineva õppijakeele analüüsi kohta: esimene neist keskendub erinevustele keelte vahel, teine õppijakeele vigadele. Kahelda tuleb ka niisugustes korpuslingvistilistes õppijakeele uurimustes ja keeletehnoloogilistes arendustes, mille aluseks on võetud õppijakeele vigaste lausete paralleelistamine vastavate n-ö õigete lausetega, mis oma äranägemisel on lisanud korpuse tehniline töötaja või erinevad uurijad. Siinkohal peaks silmas pidama vähemalt kahte olulist momenti. Esiteks on vigade interpreteerimine ja parandamine individuaalne, sõltub uurija teadmistest ja võimest seoseid näha. See protsess ei tugine ühtsele arusaamale vea olemusest - tegu on subjektiivsete seinast seina tõlgendustega. Teiseks on õppijakeel samasugune keelekasutusvariant nagu nt kirjakeel või murdekeel - neid kõiki iseloomustab terviklikkus ja kontinuaalsus, mis ei tule esile, kui analüüsitakse üksikobjekte nagu keelend, lause või keeleviga.

Uurimistöö seisukohalt on oluline erinevate keelekasutusvariantide ja keelte võrdlev korpusanalüüs, et aimu saada, missugused protsessid keeles toimivad - seda nii keeleteooria, keeletehnoloogiliste rakenduste loomise kui ka keeleõppe eesmärgil, kuna kasutuspõhisus seob mitte ainult erinevaid teooriaid ja uurimisvaldkondi, vaid toob välja samalaadsed arengud ja erinevused keelekasutuses ning keelte vahel, mis lubab kõige muu hulgas objektiivsemalt hinnata ka keelekasutuse aktsepteeritavust. Seejärel võib hakata mõtlema, millest saadud andmed meile räägivad. Eesti õppija- ja kirjakeele objektikäänete kasutust analüüsides olen seda integreeritud lähenemist jõudu mööda rakendanud. 


\section{Tänusõnad}

Artikli valmimisel on olnud toeks "Eesti keele keeletehnoloogiline tugi (20062010)" projekt "VAKO: Eesti vahekeele korpuse keeletarkvara ja keeletehnoloogilise ressursi arendamine (2008-2010)", riikliku programmi "Eesti keel ja kultuurimälu (2009-2013)" projekt "REKKi käsikirjaliste materjalide digiteerimine, Eesti vahekeele korpuse alamkorpuste loomine ja korpuse kasutusvõimaluste populariseerimine (2009-2013)", Eesti Teadusfondi grant 8222 “Ülekantud tähenduses fraasid eesti keele korpustes" ja Eesti Teadusfondi grant 8240 "Lähtekeele mõju ja teise keele omandamine: korpuspõhine uurimus".

\section{Kirjandus}

Aikhenvald, Alexandra Y. 2007. Grammars in contact: A cross-linguistic perspective. - Alexandra Y. Aikhenvald, R. M. W. Dixon (Eds.). Grammars in Contact: A Cross-Linguistic Typology. Explorations in Linguistic Typology Series 4. Oxford: Oxford University Press, 1-66.

Boas, Hans C. 2002. On constructional polysemy and verbal polysemy in construction grammar. - Vida Samiian (Ed.). Proceedings of the 2000 Western Conference on Linguistics 12, 126-139.

Chang, Nancy, Jerome Feldman, Robert Porzel, Keith Sanders 2002. Scaling Cognitive Linguistics: Formalisms for Language Understanding. http://www. icsi.berkeley.edu/NTL/papers/scaling.pdf (10.05.2010).

Croft, William 2001. Radical Consruction Grammar. Oxford: Oxford University Press. doi:10.1093/acprof:oso/9780198299554.001.0001

Ehala, Martin 1997. Eesti morfoloogia olemus. - Keel ja Kirjandus 6, 370-383.

Ehala, Martin 2009a. Linguistic strategies and markedness in Estonian morphology. - Sprachtypologie und Universalienforschung 1 (2), 29-48.

Ehala, Martin 2009b. Keelekontaktide mõju eesti sihitiskäänete kasutamisele. Keel ja Kirjandus 3, 182-204.

Eslon, Pille 2010a. Suundumustest eesti keele grammatiliste käänete kasutuses. - Pille Eslon, Katre Õim (Toim.). Korpusuuring ja meetodid. Tallinna Ülikooli eesti keele ja kultuuri instituudi toimetised 12. Tallinn: TLÜ Kirjastus, 7-36.

Eslon, Pille 2010b. Muutustest eesti keele grammatiliste käänete kasutamisel. Lähivõrdlusi. Lähivertailuja 19, 38-60. doi:10.5128/LV19.03

Eslon, Pille 2009. Eestikeelses tekstiloomes eelistatud konstruktsioonid ja käändevormid. - Pille Eslon, Katre Õim (Toim.). Korpusuuringute metodoloogia 
ja märgendamise probleemid. Tallinna Ülikooli eesti eesti keele ja kultuuri instituudi toimetised 11. Tallinn: TLÜ Kirjastus, 30-53.

Eslon, Pille 2008. Käändevormide kasutussageduse võrdlus eesti õppijakeeles ja kirjakeeles. - Pille Eslon (Toim.). Õppijakeele analüüs: võimalused, probleemid, vajadused. Tallinna Ülikooli eesti filoloogia osakonna toimetised 10. Tallinn: TLÜ Kirjastus, 31-66.

Eslon, Pille, Erika Matsak 2009. Eesti keele kasutusvariandid: korpusest tulenev käändevormide võrdlev analüüs. - Eesti Rakenduslingvistika Ühingu aastaraamat 5, 79-110. doi:10.5128/ERYa5.06

Eslon, Pille, Katre Õim 2010a. Objektikäänete kasutamisest sageduse ja markeerituse seisukohalt. - Eesti ja soome-ugri keeleteaduse ajakiri 1-2, 69-89.

Eslon, Pille, Katre Õim 2010b. Verbi indefiniitsus ja objektikäände kasutus. - Ettekanne VI Muutuva keele päeval. Tartu, 5. november 2010. Ettekande teesid. Tartu, 5 .

Fernándéz, Marlén Izquierdo 2007. Corpus-based cross-linguistic research: Directions and applications (James' interlingual linguistics revisited). Interlingüística 17, 520-527.

Granger, Sylviane 2004. Computer learner corpus research: current status and future prospects. - Ulla Connor, Thomas A. Upton (Eds.). Applied Corpus Linguistics: A Multidimensional Perspective. Amsterdam, Atlanta: Rodopi, 123-145. http://www.fltr.ucl.ac.be/fltr/germ/etan/cecl/Downloads/Indianapolis\%20status\%20\&\%20prospects.pdf (22.12.2010).

Greenberg, Joseph Harold 1990. The relation of frequency to semantic feature in a case language (Russian). - Keith Denning, Suzanne Kemmer (Eds.). On Language, Selected Writings of Joseph H. Greenberg. Stanford (CA): Stanford University Press, 207-226.

Grünthal, Riho 2003. Finnic Adpositions and Cases in Change. Suomalais-Ugrilaisen Seuran toimituksia 244. Helsinki: Finno-Ugrian Society.

Hanston, Susan 2002. Pattern grammar, language teaching, and linguistic variation: Applications of a corpus-driven grammar. - Randi Reppen, Susan Fitzmaurice, Douglas Biber (Eds.). Using Corpora to Explore Linguistic Variation. Amsterdam, Philadelphia: John Benjamins, 167-186.

Heine, Bernd, Tania Kuteva 2008. Constraints on contact-induced linguistic change. - Journal of Language Contact - THEMA 2. Language Contact and the Dynamics of Language: Theory and Implications, 57-89. http:// www.jlc-journal.org (12.02.1011).

Hoey, Michael, Michaela Mahlberg, Michael Stubbs, Wolfgang Teubert (Eds.) 2007. Text, Discourse, and Corpora: Theory and Analysis. With an introduction 
by John Sinclair. London, New York: Continuum International Publishing Group. http://www.icsi.berkeley.edu/NTL/papers/scaling.pdfhttp://www. icsi.berkeley.edu/NTL/papers/scalin.pdf (28.08.2008).

Huumo, Tuomas 2006. Kvantiteetti ja aika I: Nominaalisen aspektinnäkökulma suomen objektin ja subjektin sijamerkintään. - Virittäjä 4, 504-538.

Kaalep, Heiki-Jaan 2010. Mitmuse osastav eesti keele käändesüsteemis. - Keel ja Kirjandus 2, 94-111.

Kaalep, Heiki-Jaan 2009. Kuidas kirjeldada ainsuse lühikest sisseütlevat kasutamisandmetega kooskõlas? - Keel ja Kirjandus 6, 411-425.

Kaivapalu, Annekatrin 2010. Mõnede eesti sõnajärjemallide psühholingvistilisest reaalsusest. - Eesti Rakenduslingvistika Ühingu aastaraamat 6, 103-120. doi:10.5128/ERYa6.07

Kaivapalu, Annekatrin 2008. Lähtekeele mõju korpuspõhine uurimine. - Pille Eslon (Toim.). Õppijakeele analüüs: võimalused, probleemid, vajadused. Tallinna Ülikooli eesti filoloogia osakonna toimetised 10. Tallinn: TLÜ Kirjastus, 93-119.

Kaivapalu, Annekatrin, Maisa Martin 2007. Morphology in transition: The plural inflection of Finnish nouns by Estonian and Russian learners. - Acta Linguistica Hungarica 54 (2), 129-156. doi:10.1556/ALing.54.2007.2.2

Kont, Karl 1963. Käändsõnaline objekt läänemeresoome keeltes. Eesti NSV Teaduste Akadeemia Keele ja Kirjanduse Instituudi uurimused IX. Tallinn: Eesti Riiklik Kirjastus.

Копотев Михаил 2008. К портстроению частотной грамматики русского языка: падежная система по корпусным данным. - Арто Мустайоки, Михаил Копотев, Леонид Бирюлин, Екатерина Протасова (Ред.). Инструментарий русистики: корпусные подходы. Slavica Helsingiensia 34. Хельсинки, 136-151.

Kostenko, Anne 2009. Postimees-online ajakirjandustekstide tõlkeanalüüs: vahendatud väite tõlkimisvõimalusi. Magistritöö. Tallinna Ülikool.

Larjavaara, Matti 1991. Aspektuaalisen objektin syntyy. - Virittäjä 4, 372-408.

Lees, Aet 2004. The case of the object in early Estonian and Finnish texts. Proceedings of the 2004 conference of the Australian Linguistics Society. http://ses.library.usyd.edu.au/bitstream/2123/113/1/ALS-20050630-AL. pdf (5.04.2011).

Lindström, Liina 2006. Infostruktuuri osast eesti keele sõnajärje muutumisel. Keel ja Kirjandus 11, 875-888.

Lüdeling, Anke, Stefan Evert 2003. Linguistic experience and productivity: corpus evidence forfinegrained distinctions. - Dawn Archer, Paul Rayson, 
Andrew Wilson, Tony McEnery (Eds.). Proceedings of the Corpus Linguistics 2003 Conference, 475-483. http://purl.org/stefan.evert/PUB/ LuedelingEvert2003.pdf (27.02.2011).

Lüdeling, Anke, Stefan Evert, Ulrich Heid 2000. On measuring morphological productivity. - Werner Zuhlke, Ernst G. Schukat Talamazzini (Hrsg.). KONVENS-2000 Sprachkommunikation. VDE Verlag, 57-61. http://purl. org/stefan.evert/PUB/LuedelingEvertHeid2000.pdf (27.02.2011).

Metslang, Helena, Erika Matsak 2010. Kesksete lausekomponentide järjestus õppijakeeles: arvutianalüüsi katse. - Eesti Rakenduslingvistika Ühingu aastaraamat 6, 175-194. doi:10.5128/ERYa6.11

Nikolaev, Alexandre, Jussi Niemi 2006. Nominien paradigmaattistuminen suomessa. Millä rakenteellisilla ehdoilla kielenkäyttäjät sitovat potentiaaliset nominit taivutusluokkiin? - Virittäjä 1, 46-69.

Nuckols, Mark Eliot 2007. Case Variation in Czech and Russian: Implications for the Transitivity Hypothesis. PhD thesis. Ohio State University. http://www. ohiolink (12.03.2010).

Pool, Raili 2010. Õppijakeele kontekstuaalne varieeruvus eesti keele täis- ja osasihitise kasutamisel. -Eesti Rakenduslingvistika Ühingu aastaraamat 6, 225-242. doi:10.5128/ERYa6.14

Posio, Pekka 2008. Uso del pronombre personal sujeto de la primera persona del singular en español y portugués hablados: factores semánticos y pragmáticos. Tesina pro gradu. Universidad de Helsinki.

Rajandi, Henno, Helle Metslang 1979. Määramata ja määratud objekt. Tallinn: Valgus.

Ringbom, Håkan 2007. Cross-Linguistic Similarity in Foreign Language Learning. Clevedon: Multilingual Matters LTD.

Sahkai, Heete 2006. Konstruktsioonipõhise keelekirjelduse võimalustest adessiivse viisi- ja põhjusmääruse näitel. - Keel ja Kirjandus 10, 816-831.

Scott, Mike 2008. Developing WordSmith. - International Journal of English Studies 8 (1), 95-106.

Sepper, Maria-Maren 2006. Indirektaal eesti 19. sajandi lõpu ja 20. sajandi aja- ja ilukirjanduses. Magistritöö. Tallinna Ülikool.

Smith, Nicholas, Sebastian Hoffmann, Paul Rayson 2008. Corpus Tools and Methods, Today and Tomorrow: Incorporating Linguists' Manual Annotations. - Literary and Linguistic Computing 23 (2), 163-180. doi:10.1093/ $\underline{11 \mathrm{c} / \mathrm{fqn} 004}$

Stubbs, Michael 1996. Text and Corpus Analyzis. Oxford: Blackwell Publ. 
Sulkala, Helena 1996. Expression of aspectual meanings in Finnish and Estonian. - Mati Erelt (Ed.). Estonian: Typological Studies I. Publications of the Department of Estonian of the University of Tartu 4. Tartu: Tartu Ülikooli Kirjastus, 165-225.

Tauli, Valter 1968. Keelekorralduse alused. Stockholm: Vaba Eesti.

Tognini Bonelli, Elena 2002. Functionally complete units of meaning across English and Italian: Towards a corpus-driven approach. - Bengt Altenberg, Sylviane Granger (Eds.). Lexis in Contrast. Corpus-based Approaches. Philadelphia: John Benjamins, 73-95.

Tognini Bonelli, Elena 2001. Corpus Linguistics at Work. Amsterdam, Philadelphia: John Benjamins.

Vaiss, Natalia 2004. Eesti keele aspekti valjendusvõimalusi vene keele taustal. Magistritöö. Tallinna Ülikool.

Õim, Katre 2009. Alternatiivseid mooduseid fraseoloogia esitamiseks sõnastikus. - Pille Eslon, Katre Õim (Toim.). Korpusuuringute metodoloogia ja märgendamise probleemid. Tallinna Ülikooli eesti keele ja kultuuri instituudi toimetised 11. Tallinn: TLÜ Kirjastus, 136-164.

Östman, Jan-Ola, Fried, Mirjam (Eds.) 2005. Construction Grammars: Cognitive Grounding and Theoretical Extensions. Amsterdam, Philadelphia: John Benjamins.

\section{Pille Eslon}

Tallinna Ülikooli eesti keele ja kultuuri instituut

Narva mnt 25

10120 Tallinn, Estonia

pille.eslon@tlu.ee 


\title{
Implications of the Estonian learner language case replacements
}

\author{
PILLE ESLON \\ Tallinn University
}

The article expounds on some trends witnessed in the use of object cases in Estonian. It is a synchronous research basing on Estonian learner language and standard language corpus-driven and corpus-based comparative language usage analysis. The corpus-driven analysis provides evidence to phenomena, endemic to a given language usage variant, followed up by corpus-based analysis. The point of reference is the concept, according to which the learner language use reflects the processes inherent to development of the standard language, manifested among others also by changes of object cases and alternating grammatical cases. Those processes would not reveal themselves, if the language system should lack the respective readiness. The comparative corpus-driven analysis of different language usage variants highlights the phenomena deriving from language transfer on the one hand, and from the Finno-Ugric substance of Estonian on the other hand, which the contrastive and error analysis incidental to word or category fails to bring to the fore.

Keywords: object cases; form variation; corpus-driven and corpus-based comparative language usage analysis; standard Estonian; Estonian learner language 